\title{
DEBATE III
}

| nterveñen:

Carlos Aymerich

José Manuel Castelao Bragaña

Anxo Lugilde

Ana Miranda

Carlos Navarro

Xosé Manoel Núñez Seixas

Lino Pellitero

Xosé Luís Rodríguez Pardo

Marisol Soneira

Ramón Villares 
Carlos Navarro: Quixera manifestar o meu agradecemento por poder participar neste tipo de foros, xa que finalmente un benefíciase máis do que recolle dos comentarios e consultas que do que un pode ofrecer; isto é especialmente certo no debate de hoxe, no cal se introduciron unha serie de temas en que eu fixen algunha incursión de xeito moi tanxencial. Con frecuencia, estes temas son abordados dende unha perspectiva máis ben técnica, política ou estritamente electoral e permiten introducirse en aspectos politolóxicos ou conceptuais de xeito marxinal. A discusión desta mañá e o maxistral resumo realizado por Xosé Manoel Núñez Seixas invitan a que nos internemos noutros aspectos aos que habitualmente non se lles concede a debida importancia.

Intentarei ofrecer respostas preliminares xa que amais entendo que a anterior sesión pretendía provocar un debate e atopar bases de consenso sobre aspectos referidos á experiencia de España e ás características do caso galego.

Acerca da existencia de parámetros ou de países modelo, quixera sinalar que non existen. As referencias que coñecemos sobre como se producen as primeiras experiencias poderían ser Nova Zelandia, Canadá e os Estados Unidos, Australia; estas poden ser un punto de partida. Entre Canadá e Australia existen afinidades, son países que se crean a partir dunha importante migración; e entre Canadá e Estados Unidos estas veñen marcadas polo recoñecemento dos dereitos políticos específicos dos militares desprazados no estranxeiro.

Na miña opinión, as experiencias -exceptuando certas analoxías entre Australia e Nova Zelandia, que son pioneiras, e entre Canadá e Estados Unidos, que as comezan a debater- son escasas. Existen poucos estudos rigorosos que documenten as orixes e os antecedentes que configuran as lexislacións adoptadas. 0 caso español e galego, en termos de investigación respecto ao tema do voto emigrante, é excepcional; soamente México se podería considerar outra excepción, dado que alí xurdiu un debate profundo e moi documentado. Pero o certo é que a nivel internacional existen abondosos baleiros e insuficiencias nas investigacións que aquí en Galicia tedes o privilexio de posuír.

Podemos destacar igualmente os casos de Colombia ou Brasil. A experiencia latinoamericana primixenia foi a colombiana, en 1960; nela atopamos razóns estritamente nacionais motivadas por un período de forte violencia, existe un período en que hai un acordo entre as dúas forzas políticas principais para que, independentemente do resultado electoral, se poidan alternar no poder. Polo tanto non se ve como unha decepción a posibilidade de incluír as diásporas no estranxeiro. Brasil é outro caso excepcional e anómalo no que existe unha lexislación aprobada polo Goberno militar en 1964, que contempla o voto no estranxeiro, pero que no entanto demoran vinte anos en poñela en práctica ante a inexistencia de eleccións.

A partir dos anos setenta, mencionabamos na outra sesión dous factores máis ou menos globais que crean un contexto máis ou menos esixente nesa materia, pero insisto, das experiencias latinoamericanas, onde puiden indagar un pouco da súa orixe e da súa evolución, en última instancia son factores e condicións estritamente internas, poden ser cálculos, motivacións políticas, presión das diásporas organizadas no estranxeiro as que levan a xerar un contexto en que non hai outra opción para os lexisladores máis que aprobar unha lexislación o máis xenérica posible; tampouco é un tema en que queiran profundar demasiado: os núcleos problemáticos prefiren evadilos e optan por disposicións máis ou menos xenéricas.

En relación á evolución das lexislacións, hai que sinalar a existencia de teorías que se remontan á antiga Roma ou ás colonias de Estados Unidos, na procura das orixes do voto emigrante. Eu considero que se trata de teorías bastante cuestionables. Na miña opinión os dous modelos que evolucionan en sentido positivo son Australia e Nova Zelandia. Nestes países o elector dispón de grandes facilidades para emitir o voto e ademais garanten a maior con- 
fianza a respecto da pureza ou integridade do sufraxio; isto é excepcionalmente importante xa que, como é sabido, ambos os aspectos non sempre son compatibles e poden ocasionar conflitos de intereses.

Cómpre sinalar ademais que as citadas evolucións non sempre son progresivas ou en liña ascendente; pola contra, existen casos en que a lexislación permite o voto no estranxeiro pero de modo moi cauto. Algunhas lexislacións, coa finalidade de evitar maiores complicacións, contemplan que o organismo responsable de organizar as eleccións será o que determine en que momento existen as condicións materiais e técnicas apropiadas para que se leven a cabo. Deste xeito a responsabilidade recae, en última instancia, no organismo electoral e óbviase que ten que ser o Congreso, dado que poden existir condicións técnicas que requiren dun complemento financeiro importante, o que subministre os mecanismos necesarios para levalo á práctica.

Panamá é un caso paradigmático ao fío do que sinalamos con anterioridade. Neste país a responsabilidade foi transferida ao organismo electoral e este, a mediados dos 90, desviou o problema ao Congreso. [...] Como consecuencia disto, no ano próximo -2009-, Panamá celebrará as primeiras eleccións no estranxeiro. Os responsables panameños seguiron o modelo mexicano e estableceron un modelo «cauto», con moitos mecanismos de seguridade e agardan, previsiblemente, niveis de rexistro e participación moi reducidos. Os resultados que obteñan no próximo ano 2009 serán decisivos á hora de introducir modificacións na súa lexislación.

Nova Zelandia é un caso excepcional, no que a correlación emigración-inmigración constitúe un interesante tema de investigación. Entre ambas existen desproporcións e eu a este respecto sinalaría que, nun sistema óptimo, o cidadán debería de votar esencialmente polas autoridades do lugar onde reside e, en orde progresiva, polas municipais, rexionais e nacionais. Emporiso, as políticas restritivas en materia de incorporación ou absorción e xa non de recoñecemento de dereitos en xeral sociais, políticos ou económicos impídeno.

Respecto das cidadanías múltiples, hai que sinalar que fronte á existencia de cidadáns privilexiados, que teñen cidadanía múltiple e que se quixesen poderían votar en catro ou cinco países distintos, están aqueles que non o poden facer nin tan sequera no lugar onde naceron, nin moito menos no lugar onde residen. Esta é a traxedia de migrantes desprovistos total ou parcialmente dos seus dereitos políticos; trátase dun feito do que hai que facerse cargo.

Polo que se refire á gradación antes presentada, considero que non é unha mala idea e, unha vez suscitado o problema, poderían existir fórmulas para afrontalo. Como é obvio, para iso, primeiramente e coa finalidade de chegar a un acordo razoable, é preciso definir cal é o problema que se quere resolver e o obstáculo que hai que superar. Con frecuencia, de forma indirecta impóñense certo tipo de restricións e o debate non se desenvolve coa fondura con que se debería. Nin tan sequera no caso mexicano se fixo. A este respecto, si se quere facer unha experiencia pioneira e orixinal, precísase dun debate a fondo sobre o tema da cidadanía e os dereitos políticos.

Estou totalmente de acordo en non incorrer no voto censitario. En México e noutros países de América Latina constitúe un debate de axenda nacional. Á presidenta Bachelet en Chile, polo menos van un par de intentos, onde pasou por comisións, elevouno ao pleno do Parlamento e por lixeiras marxes déronlle marcha atrás; explícano outras razóns, foron determinadas forzas políticas as que se opoñen sistematicamente a isto. En Uruguai, por exemplo, existiron iniciativas dende o Executivo; Tabaré asumiu un compromiso e iso xerou iniciativas de lei que non pasaron de comisións. O mesmo Ministerio de Asuntos Exteriores de El Salvador deseñou propostas para levar a cabo este tipo de iniciativas e incluso en Costa Rica, o pasado ano, arrancou unha iniciativa de lei que prosperou e superou, dende o punto de vista lexislativo, os primeiros obstáculos. Non sería estraño que durante este ano en Costa Rica se elevase ao pleno o tema do voto emigrante e se lexislase ao respecto. Ben é certo que para eles constitúe un problema relativamente menor, dado que a migración de carácter laboral e indocumentada é relativamente marxinal; por isto non presenta tantos desafíos ou dilemas coma noutros países.

Anxo Lugilde: En resposta á anterior intervención de Núñez Seixas da politóloga arxentina e a respecto de como definir os electores ausentes, en relación ao interese que estes puidesen manifestar pola política do país natal, quixera destacar a importante influencia do cruzamento de culturas políticas no caso galego. Así, no noso caso, que 
temos un 35\% do electorado exterior en Arxentina que está fortemente influenciado por unha cultura política presidencial, é dicir, é frecuente que existan certas desviacións ou síntomas de descoñecemento como froito da cultura política presidencial dos emigrantes en América, os cales descoñecen e entenden con dificultade o sistema político español. Con todo, considero que ese aspecto é menos relevante que o do propio procedemento de votación ou a regulación das campañas.

Respecto do que sinalou Carlos Navarro, o caso galego, ademais de polas particularidades cuantitativas e cualitativas que presenta, é interesante en termos de opinión pública. Trátase dun tema que desaparece momentaneamente da axenda lexislativa e non é contemplado, en moitas ocasións, do xeito que debería; porén, durante as campañas electorais e sobre todo na precampaña, convértese nun asunto central e clave, competindo coas infraestruturas, arredor do cal os partidos actúan en función das súas estratexias.

Por outra banda é moi significativo o xiro que se comeza a apreciar na opinión pública galega. Nas enquisas sobre a lexitimidade do voto emigrante realizadas a principios da presente década sinalaban grandes maiorías a favor do voto emigrante. Hoxe en día, non obstante, o panorama está mudando e a última enquisa publicada por La Voz de Galicia sinala que só un $47 \%$ se posiciona a favor do voto emigrante e case 2/3 maniféstanse en contra do dos descendentes, que serán maioría en non moitos anos. Nesta dirección considero que o partido ou partidos que na actualidade promovesen a limpeza e a regulación do voto exterior acumularían un capital importante de cara ao interior, e promoverían unha tarefa de rexeneración democrática de grande importancia no sistema político galego.

Marisol Soneira (Deputada PSOE): Quixera aludir á posibilidade de que nun futuro os galegos non consideren a emigración como unha ferida, penso que nin sequera hoxe é considerada como tal. Ademais destacaría que o tema debe ser entendido nos xustos termos. Somos un pequeno país, de menos de 3 millóns de habitantes, e temos a posibilidade de ter fóra, dependendo de quen o afirme e partindo da base de que o CERA recolle 326 000, máis incorporacións, de descendentes, familiares, ao redor dun millón de persoas directa ou indirectamente vinculadas con Galicia. Os políticos, e sobre todo desde a crise do cono sur, estivemos vendendo que lles estamos achegando sen recibir nada a cambio, porque naquel momento a situación era, verdadeiramente, tráxica, pero non caemos na conta de que a inmensa maioría non recibe nada nin necesita nada. Hai pouco celebrouse en Santiago un congreso, a onde viñeron empresarios moi potentes e outros, que polas datas -xaneiro, verán para eles-, quedaron alá e isto representa para nós unha grande oportunidade, non soamente no ámbito económico, senón tamén noutros campos: académico, deportivo, artístico ou político. Somos unha parte do mundo, modesta, que ten a honra de establecer o distinto carácter galego dos presidentes de Arxentina, e hoxe quen manda en Cuba son dúas persoas que teñen a súa orixe en Vilalba; pero polo camiño hai de todo: deputados, senadores, alcaldes, profesores universitarios, militares de alto rango, temos de todo. Como os integramos? Certamente, nunha democracia o que non vota non conta, eu estou profundamente convencida, e pensar que as cousas son distintas é autoenganarnos. Debemos considerar o feito de que se trata de xente que non precisa de nós e que para poder integralos hai que permitirlles que voten. Considero que, dende o momento que decidísemos que os emigrantes non votan, estes deixarían de ser tidos en conta.

Por outra banda coido que estamos confundindo o modelo co método. Modelo: eu son unha firme partidaria da circunscrición única e considero que no noso modelo de partidos non é máis determinante que exista unha circunscrición ca que existan cincuenta e dúas. A todos aqueles que teñen medo a que a emigración decida, quero sinalarlles que nun sistema democrático non se pode cuestionar isto; nun sistema democrático non podemos ter medo porque entón teremos medo que decidan Lugo e Ourense, poño por caso, que para ter un deputado necesitan a metade de votos que A Coruña e Pontevedra, e isto non se cuestiona, é unha decisión política para primar a dúas provincias en función de determinados feitos - provincias en regresión demográfica e económica, etc. No noso sistema de partidos non eliximos aos emigrantes para o Congreso ou para o Senado ou Parlamento, senón que eliximos entre PP, BNG e PSOE, no caso galego, e despois eses deputados ou senadores dilúense nos respectivos gru- 
pos e non teñen máis capacidade de influír que un deputado de Soria, Barcelona ou Almería. Se realmente o noso sistema fose un modelo maioritario coma o anglosaxón, talvez poderiamos falar noutros termos.

Dende o meu punto de vista o problema reside no método. Cambiar á circunscrición única significa modificar a Constitución e, evidentemente, para iso faise preciso buscar consensos entre os dous partidos maioritarios do Estado, que, de non producírense, non se levaría a cabo.

En relación ao método desexaría reflexionar sobre unha cuestión: por que queren ser nacionais? En resposta a esta pregunta cómpre sinalar primeiramente que a calquera español que lle naza un fillo no estranxeiro e este sexa inscrito no rexistro consular é español de orixe; unha vez que cumpra dezaoito anos deberá ratificar a súa nacionalidade e esta non é incompatible con outra que puidese ter.

Hoxe en día, a realidade é que resulta atractivo ser español na medida en que existe unha vinculación emocional e unhas raíces, incluso existe un compoñente económico ou académico, pero ademais, e sobre todo, posuír pasaporte español significa ter acceso a un gran mercado de traballo. Polo tanto aqueles que solicitan a nacionalidade española non necesariamente teñen intención de vir, senón que procuran unha especie de salvagarda. Isto tivemos ocasión de aprecialo en Arxentina; cando estoupou a crise foron moitos os que solicitaron a nacionalidade apresuradamente, non coa intención de vir, senón como unha forma de garantía para o seu fillo. O noso sistema permite que estas persoas poidan votar; incluso eles mesmos interiorizan que se España lles fai entrega dun pasaporte teñen a obriga moral de participar na toma de decisións políticas, nun país que é xeneroso na concesión da nacionalidade.

Polo que atinxe aos sistemas de votación, quixera sinalar que o noso é infame e en excesivo xeneroso. Ademais de poder votar os mortos, poden votar, incluso, aqueles que non son españois e residen no domicilio dunha persoa que figura no CERA. Ninguén impide a estas persoas que se poidan facer cos documentos e os introduzan nunha oficina de correos; ademais non existen impedimentos para que se compren literalmente sacas de votos. Convén salientar que se trata de países onde España non ten de ningún modo soberanía, polo que non é posible obrigar os respectivos servizos de correo a que sigan unhas determinadas instrucións. En números absolutos Bos Aires representa case trescentos mil españois e alí o PSOE, o PP e o resto das forzas políticas poden enviar publicidade electoral. Un servizo de correos externo, nun proceso de eleccións, vai ter que distribuír millóns de efectos electorais e, ademais, terá que recoller a documentación que se envía ás oficinas electorais, distribuíla e posteriormente recollela e mandala novamente. Digámoslle ao noso servizo de correos que temos que xestionar as eleccións arxentinas con fidelidade, que teñen que converterse en notarios da legalidade dun país estranxeiro e ademais que este proceso se cumpra con rapidez e pulcritude. Estoume a referir ás debilidades do noso método. Se isto acontece estarían a UXT, CC 00 e CIG manifestándose no Obradoiro, e semella que con razón.

Polo que respecta ao tema das campañas electorais considero que somos uns hipócritas. Aceptamos que existan mitins na praza do Obradoiro, pero non en Bos Aires, aceptamos que nos mitins da praza do Obradoiro, ao final do acto, invitemos aos asistentes a un viño, pero se isto acontece en Bos Aires dispáranse as críticas; aceptamos que nos medios de comunicación españois todos os partidos durante a precampaña mostren publicidade sen chegar a pedir o voto, pero o mesmo feito en Mar del Plata representa unha especie de afronta nacional, cando en realidade non o é. Como non o é, a pesar do que digan os meus compañeiros de Madrid, que un grupo de persoas que se pasan de devoción polo líder, creo que foi en Perú, digan que Mariano Rajoy é a conxunción de todos os astros. Iso é que alguén se pasa de devoción, pero tamén ocorre aquí. Hai que poñer as cousas no seu lugar. 0 certo é que en Madrid non existe a sensibilidade que temos en Galicia respecto a este tema. Cando se aborda a problemática inmigrante noutras comunidades do Estado, os partidos xuntan máis os seus esforzos cara á presión inmigratoria, cara á integración sen conflitos e a garantía de dereitos políticos de participación.

En definitiva, tratase de cuestións que se poden solucionar a medio prazo sempre que exista consenso acerca da cuestión do voto en urna e a modificación do método. Nesta mesma dirección, poderíase debater o tema do voto nas municipais, dado que, que por outra banda, estas soamente son de interese para aqueles emigrantes de orixe, 
que permanecen vinculados ao lugar onde naceron; pola contra, aos fillos e netos resúltalles indiferente exercer o voto e o que realmente lles interesa é o pasaporte da Unión Europea, o cal lles abre as portas en Europa para entrar como «cidadáns de primeira».

Cómpre resaltar que son cuestións máis sinxelas do que podemos pensar a priori. Moitos emigrantes galegos en Arxentina, por exemplo, fixéronse nacionais porque era obrigatorio para acceder a algúns cargos administrativos. Quero subliñar con isto que o que é realmente importante non é o dereito ao voto en si, senón a definición de quen ten o citado dereito, sen que isto se expoña en termos absolutos.

Novamente quixera insistir en que comparto a circunscrición única para o Estado e pareceríame unha barbaridade que os nosos emigrantes non puidesen participar politicamente nesta comunidade autónoma. Con anterioridade abordouse o tema identitario, a este respecto considero que o Centro Galego da Habana é un sinal de identidade de tan grande envergadura coma a catedral de Santiago; con isto pretendo sinalar que se trata dunha realidade que está moi presente e sen a cal non podemos entender este país. Neste contexto, en que se non votas non existes, é innegable que precisan dunha representación.

Carlos Aymerich: Tratouse anteriormente o tema dunha coalición, a este respecto e a ao fío das túas palabras quixera indicar que, en realidade, non sei a que parte pertences, porque parece que ti do PSOE non es. Temos un sistema compartido que gobernou durante catro anos no Estado, que tiña maioría e modificou a lei electoral, o sistema segue igual, refórmase a Lei de nacionalidade e o Código civil, dende o BNG advertimos que era unha irresponsabilidade reformar o Código civil en materia de nacionalidade sen reformar ao tempo a lexislación electoral, non a reformastes; con todo, esta non foi reformada a pesar de que dende o BNG se expuxeron alternativas e propostas sobre a mesa. Resulta paradoxal que neste momento, a un mes escaso dunhas eleccións xerais, esteas aquí a denunciar as irregularidades e todas as trampas que permite ese sistema electoral que temos e que vós mesmos permitides que siga existindo; así que eu espero calquera cousa.

Por outra banda, quixera manifestar que me declaro en inferioridade de condicións. Marisol Soneira acaba de chegar de Arxentina, coincidindo co proceso de selección de persoal para a delegación da Xunta de Galicia en Bos Aires e se non me equivoco coincidindo tamén coa contratación dalgúns axentes electorais que, como xa recoñecera Ismael Rego, existían xa nas municipais. De aí que eu preguntase anteriormente acerca desa figura do axente electoral e a respecto de si se coñecía no dereito comparado. Como puidemos escoitar parece que non. Esta é a situación.

Din os politólogos que as democracias liberais caracterízanse, polo que atinxe ás eleccións, porque as regras son certas e o resultado é incerto. No caso do voto emigrante en Galiza é xustamente á inversa: as regras son incertas e o resultado é certísimo. É obvio que vai gañar sempre o partido que posúa consulados, embaixadas... e, como sinalou Anxo Lugilde, no debate da mañá, esta é unha regra que non se ve desmentida nunca.

Daquela temos un sistema que, ademais de permitir a fraude, aléntaa. Considero que está concibido de propósito para que poida existir suplantación de voto, ademais de padecer outras eivas que foron comentadas por Marisol Soneira con anterioridade. Polo tanto, posuímos un sistema que está desacreditado socialmente. Parto da base de que a proposta do BNG foi posta sobre a mesa cando fomos convocados polo señor Méndez Romeu, conselleiro da Presidencia, agora estamos á espera de que o PSOE e o PP expoñan a súa respectiva proposta. Atopámonos no medio dun debate entre partidos, dentro das propias organizacións políticas, pero tamén dun debate social. No momento presente seguimos pensando e reflexionando arredor do tema.

Quixera manifestar que nós non estamos de acordo, iso non pasa en ningún país do mundo. Supón unha quebra democrática gravísima que teñamos dous millóns de electores dentro e un millón de electores fóra, estes votando cos mesmos dereitos, non nas mesmas condicións porque é máis doado votar fóra que votar dentro, e coa mesma capacidade de decidir quen goberna en Galiza. Adianto que isto non acontece en ningún país do mundo e que para nós é inasumible; non pode ser que $1 / 3$ do corpo electoral estea fóra e decida; ademais estamos falando, non só de netos, tamén de bisnetos, tataranetos... que xa votan no país onde residen. 
Verbo disto gustaríame formular, en primeiro lugar, unha cuestión: que acontece nos casos de dupla nacionalidade? Estamos nun momento de globalización e isto supón fenómenos positivos dende o punto de vista xurídico. Neste marco, posibilítase a comunicación de ordenamentos, por exemplo, en materia social para totalizar períodos de cotización ou en materia de acceso ás pensións, estanse a cruzar datos; ademais pónense en contacto os ordenamentos á hora de evitar a dobre imposición... pero, en materia electoral segue a existir unha incomunicación absoluta. Considero, a este respecto, que resultaría ben fácil cruzar os datos de Arxentina e tratar da dobre nacionalidade, co fin de comprobar que persoas exercen os seus dereitos políticos nese país. É evidente que non podemos falar de supercidadáns, como acontece na doutrina portuguesa, que teñan dereito a decidir en dous estados. Con todo, é ben diferente que aqueles dispoñan da nacionalidade e que con pasaporte español poidan vir evitando pasar pola lei de estranxeiría.

Considero que esta realidade indica o índice de hipocrisía coa que se abordan estas cuestións. Refírome a aqueles que sendo netos de emigrantes poderían acceder á nacionalidade e polo feito de non teren accedido e non posuír pasaporte español estáselles a negar o visado nos consulados españois en Arxentina. Isto evidencia que, para eses efectos, seguen a ser considerados como estranxeiros. Todo isto é sen lugar a dúbidas expresivo do que realmente se persegue.

Debemos seguir reflexionando e elaborar, dentro do proceso de recuperación da memoria, un discurso sobre a emigración, sobre a diáspora, un marco diferente de relacións entre Galiza e a súa diáspora, entendida como unha comunidade de orixe galega, establecida con carácter estábel noutros países. Ademais de definir que tipos de dereitos se lle poden recoñecer, eu considero que a solución pasa por unha vía de gradación, que significa, inescusablemente, separar nacionalidade de dereito de sufraxio. Doutro xeito o resultado é tremendamente inxusto e estamos arriscándonos a desacreditar o conxunto do proceso democrático en Galiza. A cidadanía dificilmente soportaría que un terzo de electores residindo fóra decidisen quen goberna e quen nos representa. Quixera subliñar que isto non é que non o comparta o BNG, e que non o comparte a maioría da cidadanía galega que reside dentro do país.

Ante esta realidade, cal é a nosa alternativa? É preciso que definamos quen ten dereito a voto. Nós consideramos que debe ser a primeira xeración, a segunda e seguintes xeracións, sempre e cando residisen algunha vez en territorio galego; dado que isto é o que realmente mostra certo interese, tal e como se denomina no dereito electoral portugués, esa é a ligação efectiva cunha comunidade nacional. Consideramos que esta sería unha fórmula non precisa do establecemento, nin sequera, dun límite temporal e que pode levarse a cabo sen reformar a Constitución. Pola contra, pode ser viable a través dunha Lei orgánica como a do Réxime electoral, co obxectivo de regular o exercicio dun dereito.

En segundo lugar, no caso da dupla nacionalidade, sinalamos que é necesario o cruzamento de datos, como xa se indicou anteriormente. Este non require, tampouco, ningunha reforma legal e xa se está a facer noutros ámbitos como o social ou, en tempos pasados, para controlar o servizo militar. Presupoño que no marco actual de desenvolvemento da electrónica e das TIC, esta práctica non resulta complexa de existir vontade política para facelo.

Considero que hai que modificar o sistema electoral e é ben certo que a cuestión da circunscrición electoral é un tema de debate, porén, en todo caso, considero que expoñelo neste preciso momento ten un marcado carácter oportunista. Resulta evidente, a este respecto, que hai debates que rexorden cando chegan as eleccións, pero igualmente existen propostas que tamén rexorden no mesmo contexto coa intencionalidade de tapar a campaña que se fai fóra. Isto é unha vergoña en termos democráticos e adianto que o BNG non vai facer campaña fóra, nin vai utilizar as capacidades que posúe por estar gobernando na Xunta para facer campaña fóra. Non o imos facer a pesar das consecuencias que isto poida ter.

Sostemos que non deben participar nas eleccións municipais e a este respecto quero sinalar que se trata dun debate aberto o feito de que puidesen participar nas eleccións autonómicas, formulado na Lei de eleccións ao Parlamento de Galicia e que requiriría unha reforma do Estatuto. Este establece como circunscrición a provincia e enga- 
dir unha circunscrición específica non deixaría de carrear problemas. En calquera caso, mentres non exista esa reforma da Constitución e se participan para as eleccións a Cortes Xerais, o censo electoral ten que computar para efectos internos para a determinación dos escanos que lle corresponde escoller a Galiza. Neste marco, os partidos españois estatais non están de acordo, dado que os deputados que se lle acrecenten a Galiza, polo cómputo de electores, supón restalos a outras circunscricións, e isto implica problemas maiores.

Polo que atinxe a como se vota, consideramos que hai que votar en urna, nos consulados e demais centros oficiais españois, mesmo no centro de carácter asociativo para achegar aos electores a posibilidade de votar. Amais cremos que debería regularse a campaña electoral; neste momento descoñecemos como se financia a campaña electoral fóra. Non existe regulación acerca do uso dos medios que ten a administración exterior española nin a administración galega no exterior. Pero existen informacións preocupantes -Fundación Galicia Europa ou correos electrónicos convocando a actos do PSOE- que non son un sinal tranquilizador acerca do espectáculo ao que poderemos asistir.

$\mathrm{Na}$ actualidade atopámonos á espera de coñecer respostas e nós, como xente paciente que somos, continuaremos á espera; posiblemente asistiremos a unhas eleccións xerais con estes espectáculos de turismo electoral.

Castelao Bragaña: Quero felicitar ao Consello da Cultura Galega, aos relatores e de forma especial ao seu presidente por convocar este debate.

Quixera formular primeiramente unha pregunta: algunha vez nos preguntamos que pensa España da súa emigración no exterior? Nesta cuestión atópase a base de todo. Debemos considerar se España quere que se prolongue a súa presenza no mundo a través do seu sangue ou quere facelo a través das súas empresas.

O primeiro que hai que destacar é que a emigración se construíu sobre o sentimento, quen así non o considere está nun erro. Isto é decisivo para comprender e apreciar as diferentes cuestións do tema que estamos a abordar. En política é fundamental saber aceptar diferentes opinións, aínda que a título persoal un poida discrepar. Con todo, é preciso ser definido e non debemos xogar coas persoas, e menos coa seriedade que aquela xente merece. Precisamente isto é algo que non se vén facendo. Dito isto, quixera facer unha manifestación en nome da xente da que formo parte porque se ben son membro do Partido Popular tamén son un emigrante e neste carácter morrerei. A este respecto sinaláronse contribucións valiosas dos emigrantes (o himno, a bandeira, a Real Academia, A Esmorga ,... e outras tantas cousas) pero esquecémonos de Galicia. É preciso ler a obra de Vicente Peña para decatarse de que os emigrantes fixeron moitas cousas en Galicia e trataron de educar aquel pobo do que partiron analfabetos; isto que é substancial, ás veces aquí esquécese.

En segundo lugar quixera destacar a importancia de coñecer o posicionamento que teñen no exterior. Neste debate estivemos tratando os dereitos de persoas ás que non escoitamos. Deberiamos abrir este debate e que puidesen opinar, non soamente nós mesmos, senón todos os implicados no tema.

No tocante á repercusión que o debate alcanza, é igual no resto de España que en Galicia? Sinto tristura ao escoitar determinados comentarios sobre os galegos que están no exterior.

Considero, ademais, que debemos reflexionar sobre a necesidade de establecer un debate con maior profundidade dentro dos propios partidos políticos, incluído o meu. Todos nós deberiamos abordar debates profundos coa finalidade de pronunciarnos cunha voz. Sobre esta cuestión debo sinalar que frecuentemente escoito e leo declaracións entre os diferentes integrantes dos partidos políticos que evidencian unha diversidade de opinións dentro do mesmo partido. Evidentemente, iso provocou a propia confusión da sociedade galega.

En alusión ás estatísticas citadas anteriormente, quixera sinalar que no mes de abril do ano 2007, en La Voz de Galicia, publicouse un informe acerca da participación dos galegos emigrados. Segundo este estudo, o 46\% opina que estes deben votar en todas as eleccións; o 35\% sinala que non deben votar en ningunha. En relación aos descendentes: o 22\% afirma que deben votar en todas as eleccións, o 64\% opina que non deben votar en ningunha. Resulta obvio que dalgún xeito alguén foi alimentando estas tendencias e curiosamente no día de onte, o mesmo xornal publica un informe sobre se os emigrantes deberían elixir os seus propios deputados. Os resultados 
son os que seguen: declaran que si o $15 \%$, mentres que declaran que non o $85 \%$. Ante estes datos debemos reflexionar sobre que é o que está a acontecer.

A sociedade galega hoxe en día e de xeito maioritario opina que os emigrantes non deben participar en nada, por que? Considero que as causas hai que buscalas no feito de que foi retratada unha situación dramática, na que se puxeron en evidencia moitas irregularidades e como consecuencia disto a solución máis fácil e que non interveñan en nada. Pero eu creo que a solución non pasa por isto.

Quixera vincular o sinalado anteriormente coa cuestión da creación das circunscricións. Non vou abordar as posibilidades de crealas ou non crealas, simplemente quixera facer unha reflexión. Cada vez que acontece algo na emigración responsabilizamos os galegos da emigración; eu pregúntome se as sociedades galega e española están preparadas para crear unha subscrición electoral onde se elixan dous ou tres, cinco ou un deputados. Que acontecerá cando ese/eses señor/es tomen un avión e cheguen a Santiago a definir o destino desta terra? Debemos reflexionar sobre isto. Hoxe eles están votando «antes», no tempo, e están sendo responsables do resultado obtido «despois»; polo tanto, que sucederá cando a responsabilidade recaia nun home, que deposita un voto e vai definir quen vai gobernar en Galicia? Hai situacións como a seguinte: ocorría en Pontevedra cando se ía decidir o resultado das eleccións en Galicia coa emigración, un candidato a alcalde que dicía que os veciños da súa vila, Catoira, dixesen que o que pasaba era un escándalo pero, son as regras de xogo, non? Como os emigrantes ían cambiar o destino que o pobo galego se dera? Se agora se cuestiona os emigrantes, que fariamos nesta outra situación? Cal sería a resposta? Realmente considero que isto é substancial e deberiamos esclarecelo antes de considerar quen debe votar, como debe votar e cal e o alcance que debe ter.

Desexaría citar un parágrafo do preámbulo do Estatuto de la ciudadanía española en el exterior, instrumento que valoro, se ben resulta un pouco retórico, que di: «España debe considerar a su comunidad emigrante como un auténtico capital social, su compromiso con su tierra de origen la convierte en un recurso fundamental para la proyección de España en el exterior. Parte fundamental de este capital social está compuesto por miles de españoles no nacidos en España que residen por todo el mundo, ellos también son parte del presente de nuestro país y debemos considerarlos actores imprescindibles en la construcción del futuro; uno de los fenómenos que más enriquece a muchos de los centros de emigrantes españoles es la participación activa de los ciudadanos no españoles en el desarrollo social y cultural de los mismos. Es conveniente que los poderes públicos reconozcan esta realidad y que la fomenten». Realmente recolle unhas magníficas palabras. Este estatuto prevé o voto en urna, do que tanto falamos hoxe aquí, foi aprobado por unanimidade e non obstante o voto en urna aínda non está vixente. Cando este non figura, figura a circunscrición electoral coas observacións que acabo de sinalar, nin sequera estou sinalando se é bo ou malo. Defendino porque institucionalmente non me quedaba outra opción, posto que non era a miña opinión persoal, senón a do Consejo General de la Emigración, que no último pleno reiterou o mesmo.

Se as posicións, como parece, están claras, agora o que precisamos definir é o que realmente desexamos. 0 día que esta decisión se formule posiblemente esta resulte admisible, pero mentres esteamos a preocuparnos por obter o mellor resultado en función das opcións e das decisións electorais que se adopten, a decisión non terá continuidade e o único que provocaremos é unha verdadeira confusión e unha descualificación de xente que non ten nada que ver.

Ramón Villares: Quixera aclarar, dado que o señor Castelao Bragaña fixo unha invocación acerca da posibilidade de que este debate tivese maior eco, que intentamos con todas as nosas forzas transmitir este debate a Bos Aires, rememorando deste xeito algunhas pasaxes celebres da época da República e do Estatuto. Pero por cuestións técnicas, alleas a nós, non foi posible. De non ser así, agora mesmo estarían escoitando as súas palabras unha parte da colectividade reunida na delegación de Galicia en Bos Aires. Espero que noutra ocasión se poida concretar e que poidamos culminar este desexo. 
Ana Miranda (BNG): Parabéns por esta iniciativa, que representa un paso importante no debate, non só entre as forzas políticas, senón tamén entre os responsables do mundo académico, medios de comunicación e cidadáns.

Quixera referirme ao meu caso persoal, dado que politicamente xa foi expresada aquí a posición da miña organización política. Voume referir ao residente ausente, é dicir, o residente no exterior. Por certo, que esta consideración de «residentes ausentes» foi modificada por unha emenda do BNG no Congreso dos Deputados da deputada Olaia Fernández, na que se substituía a definición de «residente ausente» pola de «residente no exterior», despois amplamente consensuada. Son residente no exterior dende 1997 e cumpro todos os requisitos que mencionamos aquí: unha filla nada en Bélxica que adquire nacionalidade española, que con 18 anos terá que optar, pero non podo votar nas urnas e cando quero exercer o meu dereito no consulado a urna non aparece e o funcionario tampouco. Estou a falar de Bélxica, da capital europea, un lugar onde existen garantías para exercer o voto con certa lexitimidade. Nas últimas eleccións, nas municipais, non votei, pero voto nos restantes procesos e non o fixen naquelas porque ao estar censada en Bélxica o sistema permite, como cidadán comunitario, votar nas elección municipais belgas, onde ademais o voto é obrigatorio. Cando fun votar dirixinme ao Consulado, onde non atopei ninguén, a urna estaba precintada, e estamos falando de Bruxelas! Posteriormente fun ao servizo de correos, presentei o meu DNI, pero non foi aceptado e esixíanme a carta de residente belga. Naquel momento non a levaba comigo así que mostrei un pase de identificación do traballo, curiosamente este si foi válido. Con isto pretendo mostrar que o sistema é vulnerable en calquera lugar do mundo.

Deste lado, do lado da emigración, gustaríame sinalar, señor Castelao Bragaña, que discrepo a respecto do que vostede sinalou dos debates no interior das propias forzas políticas, considero que isto non é aplicable a todos os partidos políticos, diría xustamente á inversa, non hai suficiente debate. No caso do BNG, dáse a casualidade de que lle foi encargada a responsabilidade da Comisión da Emigración, que asumín eu e en anos anteriores o señor Aymerich, a un emigrante ou a unha residente no exterior. A este respecto deberiamos reflexionar sobre o propio concepto de emigrante hoxe en día. Que somos os traballadores mozos que marchamos de Galiza e residimos en diferentes países comunitarios e que cada día nos erguemos consultando a prensa galega e que vimos a Galicia cada mes e que estamos informados pero que residimos noutros estados?

Cómpre sinalar que o concepto de identidade muda, estamos nun momento en que as identidades son portátiles, asistimos a un momento histórico no que aparece un novo concepto de cidadanía transfronteiriza. Isto débenos facer reflexionar e obriga a que as forzas políticas e os medios de comunicación abran un gran debate sobre a participación da nosa diáspora, como concepto, non simplemente como participación política. A sociedade galega é unha sociedade diaspórica e, neste momento, deberiamos mudar a terminoloxía e falar de diáspora no canto de emigración, xa que a emigración é o feito e a diáspora é a consecuencia.

A diáspora galega existe e ten unha connotación profundamente cultural, con todo, esta carece da suficiente información. Nesta dirección quixera referirme a un tema ao que aludiu anteriormente Anxo Lugilde, sobre a televisión galega, os medios de comunicación e as posibilidades de acceso á información. Nin no ámbito interno galego nin no externo existe información un do outro. Cando eu me conecto cos meus compañeiros do BNG en Bos Aires e Montevideo percibo que estas persoas están informadas do que aquí acontece, pero a maioría destas persoas, menores de cincuenta anos, sinalan que non participarían [nas eleccións], este é un consenso entre a diáspora, e que ademais precisan dun maior acceso á cultura. Hoxe en día, por exemplo, en Bos Aires non existe un lectorado de cultura galega onde se ensine o idioma. Recentemente convocáronse prazas na delegación da Xunta en Bos Aires e para poder concorrer esixían o certificado de lingua galega, o CELGA. Para a obtención deste esíxese ter cursado o bacharelato en Galicia ou ter realizado cursos de perfeccionamento, que desgraciadamente non foron impartidos alí, exceptuando aqueles que, de xeito puntual, foron realizados nalgún centro ou na Cátedra de Cultura Galega da universidade de Bos Aires, pero nunca de xeito regular. Comparativamente sabemos que isto é ben diferente no caso do Goethe Institute ou do Instituto Italiano de Cultura; non temos nin a mesma información nin as mesmas posibilidades. 
Considero que o debate mudaría considerablemente se aos galegos de segunda xeración, que teñen dereito a voto, se lles ofrece acceso á cultura, como Carlos Aymerich comentaba, e á participación no mundo empresarial, como sinalou Marisol Soneira. É dicir, tórnase necesario e urxente abrir un consenso arredor dun debate «elástico».

Con frecuencia falamos da fenda dixital e igualmente eu considero que existe unha fenda informativa emigrante, aquí e alá; e poderiamos preguntarnos: alá por que? Nos últimos anos os dereitos de participación política foron vinculados ao sistema de axudas sociais e facilidades de diferentes tipo: viaxes, etc., esta vinculación foi auspiciada polo PP de forma extrema. A este respecto considero que é necesario desvincular esta relación. Debemos transmitir a idea de que non hai que votar a un partido para obter un beneficio; nesta dirección é importante que desfagamos esa pérfida relación, que existiu nestes últimos anos, e isto pódese facer a través da información. Dende o momento en que o uso da televisión galega na maioría dos estados latinoamericanos é por cable e que o pagamento do cable ten un custo, o acceso á información está sendo restrinxido e isto implica que non existe entón unha igualdade informativa.

Por outra banda, o sistema existente incide na descualificación do individuo e culpabiliza ao residente no exterior de que o sistema non funcione. Quixera resaltar que isto non é certo. Ademais o sistema, auspiciado por partidos políticos de ámbito estatal, non se quere reformar; insisto, non existe vontade política para reformalo, esta é unha realidade que debemos considerar.

Neste marco, coido que no ano 2009 persistirá o mesmo debate e continuaremos indo ao Consulado de Bruxelas a procurar o funcionario. Polo tanto, é momento dun pacto e ese pacto ten que ser explicado alá. As restricións deben ser explicadas con madurez política, con transparencia e creando un gran consenso. Debemos impulsar, a nivel galego, un enfoque totalmente diferente da realidade diaspórica, non nun compartimento estanco, como pode ser a Secretaría Xeral de Emigración, senón a través dun pacto transversal para que todas as áreas de influencia incidan no exterior. Neste punto quixera remitirme ao caso irlandés, onde as competencias en materia de emigración e a relación cos centros irlandeses do mundo están inseridas no Ministerio de Asuntos Exteriores. Insisto en que é necesario en primeiro lugar un consenso, referido a esa consideración de diáspora como potencial, e en segundo lugar debemos rematar con esta hipocrisía.

Tanto o Partido Popular como o PSOE xogan coa falla de información en América. Cando se contrata axentes que van en bicicleta, como foi o caso en Montevideo, cando se paga polo voto como se fixo e hai denuncias sobre isto, é normal que aquí exista unha imaxe de voto deslexitimada. A este respecto debo sinalar que na nosa organización nunca se produciu un caso disto, eticamente non nos interesa. Chegado este punto quixera destacar que as forzas políticas estatais tamén deberían facer autocrítica dos seus procedementos, que en moitas ocasións propician que se deslexitime a imaxe que aquí temos da diáspora.

Anxo Lugilde: Quixera efectuar unha última intervención. Realmente tal e como sinalou Marisol Soneira trátase dun sistema verdadeiramente infame, pero ben é certo que os tres partidos deberían arranxalo dunha vez. É un sistema tan infame que eu creo que se en lugar de estar Kirchner na casa Rosada en xuño de 2005 estivese Carlos Saúl Menen, grande amigo do Partido Popular, seguramente o resultado das eleccións galegas fose diferente e o presidente da Xunta de Galicia hoxe sería outra persoa. Que isto poida acontecer é moito máis grave que o feito de que vote un neto que non está informado ou que eses votos poidan variar os resultados. Hai 47000 votos en Arxentina nas últimas eleccións autonómicas e o diario Clarín publicou un artigo sobre a axuda secreta ao triunfo dos socialistas en Galicia; non obstante, ben é certo que igualmente puido incidir no outro lado. 0 realmente inxusto é que isto poida suceder, todo o restante tamén adquire importancia, emporiso dende o meu punto de vista é prioritario que se atalle en primeiro lugar aquilo que impide a limpeza do proceso democrático.

Polo que se refire ao debate dos partidos, quixera sinalar que existen dous discursos dirixidos cara a fóra, que son os do PP e PSOE e que van intercambiando a súa posición segundo estean no goberno ou na oposición. Gustaríame resaltar a sinceridade de Marisol Soneria e a propia reflexión que fixo Castelao Bragaña, como emigrante, 
cando se refire á culpabilidade; coincido en que adoito atribuímos o que fai un emigrante ao conxunto dos emigrante, mentres que o que fai un galego faino exclusivamente el. Por outra banda, o BNG ten un discurso cara a dentro, é dicir, tras comprobar que era difícil para o BNG conseguir bos resultados na emigración, agora aposta por poñerse á fronte desa onda crecente de rexeitamento social ao voto emigrante.

Xosé Luís Rodríguez Pardo: Quixera felicitar ao Consello da Cultura Galega e a todos e cada un dos que interviñeron. Foron abordados aquí gran cantidade de aspectos e todos eles ben importantes. Tratamos cuestións que estaban refugadas, que, con frecuencia, son comentadas en calquera lugar, pero non en público como hoxe se está facendo aquí; e isto considero que é básico.

Non vou dicir que de aquí saia ningún consenso pero o que si é certo é que este é o camiño para chegar aos consensos, o camiño do obxectivo final común para andar por ese camiño e chegar a ese remate. Polo tanto o meu agradecemento persoal por me convidar e poder participar con todos vós, e o meu agradecemento a todos vós polo que fixestes.

Quixera incidir en dúas cuestións: a primeira, que o feito electoral que temos previsto para o 9 de marzo non nos debe facer perder de vista o que hai no fondo. Precisamente nese fondo reside unha realidade e é que efectivamente úrxenos unha reforma da Constitución, é posible, pero, hoxe por hoxe, iso hai que deixalo na beira do camiño, porque as próximas eleccións non sabemos como van ser nin o que deparan.

Polo que atinxe ao dereito ao voto, as Cámaras, as Cortes Xerais representan ao pobo español recollido na Constitución, no artigo 68. Este artigo recolle ademais que son electores e elixibles todos os españois que estean en pleno uso dos seus dereitos políticos e que a lei recoñecerá e o Estado facilitará o exercicio do dereito de sufraxio dos españois que se atopen fóra do territorio de España. Todos os nacionais españois están protexidos en igualdade de dereitos e liberdades que os resto dos españois; polo tanto, este é un tema que se poderá discutir noutra hora pero que hoxe por hoxe non arranxa o camiño do consenso que buscamos.

No camiño dese consenso existe outra cuestión á que aludiu Marisol Soneira e que eu considero importante, trátase do sistema electoral que permite todas estas «trapalladiñas» que acontecen, ás veces, nas consultas electorais. Todas elas están no propio sistema electoral e algunhas delas derivan, simplemente, de que aquí o sistema de votación é un sistema por listas pechadas e bloqueadas, vótase a lista completa e despois saen elixidos aqueles que deciden as oligarquías que mandan nos partidos. Por isto os emigrantes non poden elixir se nunha lista van os emigrantes e decidir a quen van votar; como tampouco existe unha paridade entre os cidadáns españois de aquí e os de alá. Isto é resultado do sistema electoral. Talvez, entre listas abertas e a obriga de ir votar resultase que as macrocifras que estamos manexando se alteren totalmente, ou talvez non.

Insisto en que os temas de fondo, os de máis profundidade, é dicir, aqueles que afectan directamente aos dereitos e liberdades recoñecidos pola Constitución, unha vez que están en vigor outras leis, son os realmente válidos tanto en Bos Aires como en Cariño e eses son os dereitos que posúen.

Polo que respecta a quen vota e en que circunscrición, quixera introducir aquí unha posibilidade interpretativa que non lesiona a Constitución, esta é, simplemente, a que pasa por utilizar para o Senado esa capacidade que teñen as comunidades autónomas de designar senadores pola comunidade autónoma que non implica á circunscrición territorial estrita da provincia; en calquera caso este sería outro posible tema de debate.

Finalmente quero agradecer novamente a invitación, estou verdadeiramente ilusionado e penso que é así como se poden facer cousas. Grazas.

Marisol Soneira: Parto da concepción básica de que eu traballo sobre temas migratorios, non por vocación inicial, senón que o descubrín na familia. Vivino nesta como a inmensa maioría e aprendín moito disto.

Anteriormente falamos da posibilidade de formular preguntas aos emigrantes para avaliar o seu coñecemento sobre Galicia. A este respecto debo sinalar que se saímos á rúa en Galicia e preguntamos quen elixe o alcalde do 
seu municipio, a afirmación maioritaria sería que os cidadáns; poucas persoas responderían que o elixe a corporación e que nós soamente eliximos os concelleiros. Con isto pretendo dicir que esta é unha realidade coa que convivimos todos os días. Polo tanto, se partimos da base de que os que están alá son tan España como os que están aquí, para nós é exactamente igual a campaña alá coma aquí. Nós non sentimos vergoña de facer a campaña fóra, talvez porque obtemos mellor resultado que o obtido polo BNG.

A respecto dos axentes electorais, reitero o que afirmou Ismael Rego no ano 2000, calculo que en América roldamos os cinco mil axentes electorais, que son os militantes que temos. En primeiro lugar e en alusión ás palabras de Aymerich, respecto dos axentes electorais, quixera dicir que eu non contratei ninguén, e en ningún caso con isto estou a pedir desculpas, simplemente eu fun falar cos meus compañeiros porque algúns partidos temos presenza en América dende a posguerra, dende o exilio republicano, e eu non teño culpa de que o Partido Socialista teña máis de cento vinte e cinco anos de historia e outros partidos non teñan tanta.

Por outra banda e coincidindo co que sinalaba Castelao Bragaña, non podemos elevar á categoría de feito xeneralizado aquilo que é anecdótico. Con isto quero insistir en que o que aconteceu na Fundación Galicia-Europa ou o que acontece na Federación de Sociedades Galegas, onde as bandeiras do Bloque Nacionalista están moi presentes, non é responsabilidade do BNG, son cousas de Paco Lores e, polo tanto, non deben converterse nun escándalo xeneralizado do voto na emigración. Non podemos ser inxustos, xa que en Galicia tamén se denuncian as irregularidades acontecidas aquí e tamén aquí se produce fraude, tal e como aconteceu nas eleccións municipais, onde se incrementaron os censos municipais que hoxe volven minguar, e con todo isto non estamos continuamente cuestionando o modelo, senón que simplemente o corriximos.

Por outra banda e en relación á utilización do termo «infame», estou a comprobar que non seguides os debates no Parlamento e polo tanto estamos facendo unha reflexión inútil. 0 termo infame, que utilizo para referirme ao noso modelo de votación fóra, está nas actas do Parlamento, en todos os debates sobre emigración. Reitero que se trata dun sistema infame creado baixo a presunción da boa fe das persoas e de sobra sabemos que hai persoas que non a teñen; hai persoas que teñen predisposición a cometer fraude na emigración e tamén aquí, así e todo as denuncias que se formularon aquí non poñen en cuestión o sistema nin o dereito que temos de votar. Subscribo a oferta de José Luis Caldera, en canto a que hai que conseguir un consenso, onde todos debemos debater e asumir que é preciso un cambio. Debemos considerar que o consenso, e isto é unha competencia do Estado, ten que ser iniciado polos dous grandes partidos, de non ser así non hai caso.

Lino Pellitero: Quixera expresar unha idea que non foi citada. Prodúceme grande preocupación o uso do termo «desafección», a respecto dos datos que foron achegados hoxe aquí, sobre algunhas enquisas sociolóxicas, nas que cada vez se distancia máis a emigración e evidencian que dende o interior se queren facer unhas devasas da participación exterior. Quixera sinalar que no exterior tamén existe, dado que unha gran parte dos emigrantes non queren estar vencellados para nada con esas irregularidades e non queren estar identificados con este tipo de cuestións que dalgún xeito os estigmatizan. Por isto un primeiro labor que deberiamos abordar inmediatamente sería corrixir todas estas irregularidades que se citaron aquí, coa finalidade de que o fenómeno do voto do emigrante recupere unha dignidade que non debe perder.

Independentemente das distintas posicións, considero que existen certos consensos. Esta mañá ofreceuse unha radiografía a nivel mundial e tras esta podemos deducir que posuímos un sistema xeneroso, talvez xeneroso de máis. Un sistema que permite que se adulteren os resultados e isto precisa de regulamentacións. Pero igualmente penso que existen máis consensos dos que a priori pensamos. A miña percepción, ao fío das observacións no exterior e das conversas coa xente dos centros e doutro tipo de asociacións, é que o voto nas municipais non é unha cuestión que se reivindique con forza. Tendo en conta isto, restaría definir a participación nas autonómicas e nestas, dende o meu punto de vista, non soamente deben participar aqueles que, dalgún xeito, se vinculan a Galicia, a través da inscrición, dos anos de residencia ou doutros mecanismos, senón que temos que pensar que nós como 
galegos, non só pola nosa propia historia senón tamén con vistas ao futuro, posuímos unha xeración que foi emigrante pero ademais outras novas que están a chegar e deben igualmente espertar o noso interese e que, non obstante, non poden participar. Considero que en ambos os casos e dalgún xeito temos que vinculalos cun sistema onde se restrinxa ou se regularice ese dereito.

Carlos Aymerich: Quixera sinalar, ao fío das palabras de Marisol Soneira, que non afirmei que ter axentes electorais fóra, pagados ou non, sexa ilegal. 0 que eu digo é que se trata dunha realidade, tal e como recoñeceu nas municipais o portavoz do grupo parlamentario socialista. Trátase dunha opción legal, na medida en que a lei española non ten nada que dicir porque a campaña non está regulada. Sabemos por informacións de prensa que posúen unha copia do censo e que van domicilio a domicilio recollendo a documentación electoral para votar por eles; iso sucede e existe unha lexislación electoral que o permite. Ben, non quixera facer ningún xuízo moral nin político sobre iso. Considero que debemos alcanzar un primeiro consenso a respecto de que isto ten que mudar e que é urxente reformalo. 0 presidente Touriño, respondendo a unha pregunta do BNG no Parlamento, sinalou que, coa reforma do Código civil e ampliándose a nacionalidade aos netos, podemos chegar a ter un censo electoral de medio millón de persoas, e incluso hai quen fala dun millón de residentes no exterior; isto parécenos excesivo e en termos democráticos inasumible.

Respecto da intervención de Lino Pellitero, desexaría sinalar que se trata dun aspecto moi importante. Considero que debemos cuestionarnos que tipo de relación quere ter Galicia coa súa diáspora, en que medida podemos fuxir e superar un certo paternalismo ademais do sentimentalismo que sempre existiron e desa idea da débeda que dende o meu punto de vista non axuda. Esa débeda da que se fala puido estar moi presente con aquelas escolas de fundación etc. pero esa conciencia social xa non existe nas novas xeracións, polo tanto teremos que establecer esta relación sobre novas bases. Esta é unha materia pendente e tórnase urxente para evitar esa desafección á que antes se aludiu. Agora ben, para isto non considero que o camiño sexa recoñecer, de forma indiscriminada, dereitos de sufraxio a todo aquel que teña a nacionalidade.

Por último, en alusión ás palabras de Rodríguez Pardo, quixera expresar que discrepo a respecto de que a Constitución recolle que necesariamente os que teñen a nacionalidade voten. Non, a Constitución o único que garante, na votación ao Congreso, porque o artigo 68 refírese ao Congreso, é que se facilite e se recoñeza a participación dos españois que se atopen fóra, pero soamente para o Congreso, porque para o resto é unha cuestión da lei, tal e como acontece por exemplo coa Lei de eleccións ao parlamento de Galicia, que limita o dereito de sufraxio ao sufraxio pasivo, por exemplo dos alcaldes. Trátase dunha determinación que se pode adaptar á lei sempre que se faga atendendo a criterios obxectivos e racionais.

Referíndome ao consenso ao que aludiu Marisol Soneira, efectivamente o consenso ten que realizarse entre o PSOE e o PP. A única reforma que se fixo recentemente en materia de voto emigrante non foi feita coa intención de incrementar as garantías, senón que esta introdúcese a través da Lei de eleccións ao Parlamento de Galicia, no ano 2005, e alonga de cinco a oito días o prazo para a recepción dos votos do exterior. Esta foi aprobada co voto afirmativo de PSOE e PP e voto en contra do BNG. Isto é un feito e debemos reflexionar sobre se incrementa as garantías ou simplemente incrementa os "oito días de paixón» aos que se referiu antes Anxo Lugilde.

A diferenza co do que acontece co voto por correo, no interior, cando se produciron irregularidades e estas foron denunciadas, e mesmo existiu unha condena, foi modificado o procedemento. 0 voto a través de representantes require intervención notarial e esta foi unha reforma que se fixo da LOREG. Isto mesmo non acontece co voto emigrante, a pesar de que existe consenso e todos constatamos que as irregularidades son algo máis que trapalladas e bastante máis que anécdotas, as únicas reformas que se fixeron non son para incrementar as garantías, aí si co consenso do PP e do PSOE, senón para todo o contrario. Esta é unha constatación que hai que ter en conta. 
Debate III

Xosé Manoel Núñez Seixas: Por alusións. Eu tampouco non pretendo facer ningún exame aos emigrantes. Moitos residentes en Galiza con dereito a voto non teñen claro moitos conceptos básicos da política galega, mais pagan impostos aquí e teñen tanto dereito coma calquera outro a opinar sobre a cousa pública. En realidade, pensaba sinxelamente advertir do difícil que pode ser establecer eses supostos criterios obxectivos á hora de establecer barreiras.

Ramón Villares: Moitas grazas. Agradézovos moito a vosa presenza aquí. Esta iniciativa do Arquivo da Emigración e do Consello no seu conxunto estaba pensada non para interferir no panorama político que actualmente se vai abrir, senón para contribuír a aclarar ideas. Con esta iniciativa coido que podemos contribuír a mellorar a información das elites políticas galegas, que son as que deciden sobre esta materia.

Aproveitaría para sinalar que, ademais de decidir sobre isto, tomen en conta, non soamente a necesidade de ver con outros ollos a diáspora, senón tamén a necesidade de integrar mellor o que foi e é a emigración no seu propio imaxinario partidario ou político, pois considero que houbo demasiado desleixo. En xeral, as sociedades que ven partir os seus emigrantes non se preocupan moito deles, mentres que aquelas que os reciben adoitan manifestar maior preocupación, ese é un fenómeno universal. Agora estamos nunha situación en que estamos recibindo inmigrantes, polo tanto, alén do voto, alén do método e alén dos procedementos, que é evidente que hai que depurar, temos unha conta pendente coa emigración como fenómeno histórico e coa nosa visión respecto dela. Se podemos contribuír a que isto vaia mudando, o Arquivo da Emigración faino na medida do posible, construiremos unha sociedade máis democrática e máis participativa. 